\title{
Effects of Production Locations and Plucking Intervals on Clonal Tea Fatty Acids
}

\section{Levels in the Kenya Higlands}

\author{
Amos W. OKaL ${ }^{1}$, P. Okinda OwUor ${ }^{1 *}$, David M. KAMAU ${ }^{2}$ and Lawrence O.A. MANG'URO ${ }^{1}$ \\ ${ }^{1}$ Department of Chemistry, Maseno University, P.O. Box 333 40105, Maseno, Kenya \\ ${ }^{2}$ Department of Chemistry, Tea Research Foundation of Kenya, P.O. Box 820 20200, Kericho, Kenya
}

Received September 29, 2011; Accepted February 12, 2012

Tea leaves contain unsaturated fatty acids which are precursors of aroma compounds. Despite uniform plucking practices in Kenya, plain black tea quality varies with locations. Variations in tea aroma and/or precursors with production area have not been established in a single cultivar under same agronomic input at different locations. Trials were conducted in five locations using clone BBK 35, harvested at varying intervals. The fatty acids varied $(\mathrm{P} \leq 0.05)$ with locations and increased $(\mathrm{P} \leq 0.05)$ with long plucking intervals, demonstrating leaf of same standard plucked at varying intervals contains different levels of fatty acids even in one location. The different increase rates in various locations might be in part the reason of the differences in aroma of black tea from different locations even when agronomic inputs are similar. Results demonstrate that harvesting at shorter intervals and developing region-specific plucking policies may improve tea quality.

Keywords: tea, Camellia sinensis, fatty acids, plucking interval, location of production

\section{Introduction}

Tea (Camellia sinensis (L.) O. Kuntze) yields and black tea quality are influenced by agronomic practices, especially plucking (Owuor, 1996). Plucking is an expensive undertaking (Ellis and Grice, 1981) and constitute up to $80 \%$ of the total field cost of tea production (Sharma, 1987). During this process young tender shoots are harvested for processing into various tea beverages. The recommended plucking standard in tea is two leaves and a bud that gives desirable good quality teas (Othieno, 1988), although there are producers harvesting mature leaf. In practice, it is very difficult to exclusively achieve the recommended standard in commercial tea harvesting as various portions of different standards leaf are usually plucked and the amount of coarse fraction and fine fraction in the plucked crop determines the overall leaf quality.

Shoots of similar two leaves and a bud can be obtained through optimizing harvesting intervals when most leaves are in the stage of two leaves and a bud. Plucking frequency is therefore an important factor which controls the

*To whom correspondence should be addressed.

E-mail: owuorpo@africaonline.co.ke proportions of different leaf standard in the harvested crop (Odhiambo, 1989) and influences yield (Owuor et al., 2009) and tea quality (Baruah et al., 1986, Owuor et al., 2009). Flavoury black teas are valued for their unique smell attributed to the levels and distribution of the volatile flavour compounds (VFC) (Robison and Owuor, 1992) while plain teas are valued for their taste, briskness and colour characteristics, which are influenced by non-volatile (theaflavin and thearubigin) components. The VFC in tea can further be classified into primary and secondary products (Sanderson and Graham, 1973). The primary aroma compounds are biosynthesized by the plant and are present in the fresh tea leaf, while the secondary products are derived from carotenes, amino acids, unsaturated fatty acids and other lipids (Robinson and Owuor, 1992) and terpene glycosides (Skobeleva et al., 1987). The VFC contributing the green grassy aroma are dominated by products of unsaturated fatty acids in the green tea leaf (Yamanishi et al., 1978, Robinson and Owuor, 1992). These VFC are composed mostly of straight chain $\mathrm{C}_{6} \mathrm{C}_{7}, \mathrm{C}_{9}$, and $\mathrm{C}_{10}$ aldehydes, alcohols and acids, which are products of unsaturated fatty acids breakdown during black tea processing (Hatanaka et al., 1995, Kajiwara et al., 1982, Sekiya et al., 1984). These compounds reduce black tea 
quality (Mahanta et al., 1988, Robinson and Owuor, 1992) but enhance green tea quality (Wang et al., 1988). Cis-4,5epoxy-E-2-decenal (Gardener and Salke, 1984, Gassenmeier and Schieberle, 1994) and trans-4,5-epoxy-E-2-decenal (Kumazawa et al., 2006) have also been reported as products of linolenic acid degradation. The levels of these compounds usually increase with increase in amounts of unsaturated fatty acids in green tea leaves (Mahanta et al., 1988). The unsaturated fatty acids in tea leaf are therefore key tea quality determinants. Although the levels of these volatile flavour compounds changed with plucking intervals in black tea in Assam, India (Baruah et al., 1986), the magnitude of changes in unsaturated fatty acids levels have not been established and it is not known whether their levels change with locations as observed in plain black tea quality parameters (Owuor et al., 2009, 2010a, 2010b) when the cultivar is the same. In the previous studies, the genetic make of the plants used and agronomic practices were varied. It is therefore not possible to assert if the noted variations were solely due to locations.

Plucking interval influences the aroma quality of black tea, especially, shorter plucking intervals improve the aroma quality of black tea (Baruah et al., 1986, Owuor et al., 2000). At single sites, the unsaturated fatty acids levels increased with maturity of the shoot (Bhuyan et al., 1991, Owuor et $a l ., 1990)$ implying a tendency to produce poor flavoury black tea with coarse plucking standard. It is not known if the levels of fatty acids of a single cultivar subjected to same agronomic management and inputs will change with location of production when same plucking standard is maintained. Changes in black tea aroma with location had been reported in Assam (Mahanta et al., 1988). Since there were changes in VFC it is likely the fatty acids may also vary. However, it is not known if the magnitude and pattern of the changes in fatty acids levels with location of production will be similar in one genotype under uniform management. Lack of similar magnitudes and patterns in changes may suggest need for varying plucking interval recommendations to enhance tea quality.

\section{Materials and Methods}

The trials were laid out in five main tea growing regions of Kenya at Karirana (altitude $2260 \mathrm{~m}$ above mean sea level (amsl), latitude $1^{\circ} 6^{\prime} \mathrm{S}$, longitude $36^{\circ} 39^{\prime} \mathrm{E}$ ), Timbilil (altitude $2180 \mathrm{~m}$ amsl, latitude $0^{\circ} 22^{\prime} \mathrm{S}$, longitude $35^{\circ} 21^{\prime} \mathrm{E}$ ), Changoi (altitude $1860 \mathrm{~m}$ amsl, latitude $0^{\circ} 29^{\prime} \mathrm{S}$, longitude $35^{\circ} 14^{\prime} \mathrm{E}$ ), Sotik Highlands (altitude $1800 \mathrm{~m}$ amsl, latitude $0^{\circ} 35^{\prime} \mathrm{S}$, longitude $35^{\circ} 5^{\prime} \mathrm{E}$ ) and Kipkebe (altitude $1800 \mathrm{~m}$ amsl, latitude $0^{\circ} 41^{\prime} \mathrm{S}$, longitude $35^{\circ} 5^{\prime} \mathrm{E}$ ). Clone BBK 35 plantations that had been uniformly managed with known past cultivation history, were selected from each site. The trials were laid out in a randomised complete block design with three plucking intervals rates $(7,14$, and 21 days) and replicated three times. The standard plucking of two leaves and a bud was done in all the plots. Each effective plot comprised 60 plants surrounded by a line of tea bushes that served as guard rows. The plots were uniformly managed and prior to and during the experiments, all the plots were receiving $150 \mathrm{~kg} \mathrm{~N} \mathrm{ha}^{-1}$ year $^{-1}$ as NPKS 25:5:5:5.

The samples were collected by plucking $100 \mathrm{~g}$ of two leaves and a bud from each plot. The leaves were steamed for 1 minute to deactivate the enzymes responsible for oxidative degradation reactions in tea leaves. The leaves were cooled, then oven dried $96^{\circ} \mathrm{C}$ to a constant weight. The dried leaves were ground to fine powder using coffee grinder. Each dried sample $(10 \mathrm{~g})$ was mixed with $0.015 \mathrm{~g}$ of heptadecanoic acid (as an internal standard) and then extracted twice with 2:1 $(\mathrm{v} / \mathrm{v})$ chloroform and methanol mixture for three hours with continuous stirring at room temperature. The mixture was shaken together with $20 \mathrm{ml}$ dilute potassium chloride solution. The organic layer was separated and solvent removed under reduced pressure.

The lipids were transesterified and esterified to their corresponding methyl esters (Owuor et al., 1990). To the lipids were mixed with $10 \mathrm{ml}$ methanolic sodium hydroxide solution $(0.05 \mathrm{~mol} / \mathrm{L})$ in a round bottomed flask fitted with a condenser. A small volume of tetrahydro furan was added to improve the solubility of the lipids. The mixture was refluxed for ten minutes. About $10 \mathrm{ml}$ of boron trifluoride-methanol complex (about $14 \% \mathrm{BF}_{3}$ ) was added and the mixture refluxed for a further two minutes. The solution was cooled to room temperature and $5 \mathrm{ml}$ hexane was added and the mixture refluxed again for two minutes. A saturated sodium chloride solution was added and the hexane layer was separated and dried with anhydrous sodium sulphate. The extraction was done twice and activated silica gel was added to the hexane layer with continuous stirring to remove all the chlorophyll. The silica gel was filtered off and hexane removed under reduced pressure using rotary evaporator. The fatty acid methyl esters were then dissolved in small amount of hexane in sample bottle before injection into the $\mathrm{GC}$

The GC analysis was carried out under the conditions reported by Munavu (1983). The GC was fitted with fused 50 $\mathrm{m}$ silica gel capillary columns coated with carbowax, (film thickness; $0.20 \mathrm{um}, 0.25 \mathrm{~mm}$ inner diameter) and flame ionization detector. The temperature programme was holding at $160^{\circ} \mathrm{C}$ for $4 \mathrm{~min}$ then increasing linearly to $170^{\circ} \mathrm{C}$ at $0.6^{\circ} \mathrm{C} /$ min and holding for $9 \mathrm{~min}$ and finally increasing to $200^{\circ} \mathrm{C}$ with a rate of $3.5^{\circ} \mathrm{C}$ per minute then holding at $200^{\circ} \mathrm{C}$ for another $4 \mathrm{~min}$. The flow rates were $3.0 \mathrm{~mL} / \mathrm{min}$ for the carrier $\left(\mathrm{N}_{2}\right), 30.0 \mathrm{~mL} / \mathrm{min}$ makeup (air) gases, and $40.0 \mathrm{~mL} / \mathrm{min}_{2}$ 
and $400.0 \mathrm{~mL} / \mathrm{min}$ air for detector gases, respectively. The detector temperature was set at $230.0^{\circ} \mathrm{C}$. Sample of $0.1 \mu \mathrm{L}$ was injected. The compounds were identified and quantified by corroborative retention times and peak area of authentic fatty acid standards relative to internal standard.

\section{Results and Discussion}

The current plucking interval recommendation is the same for all tea growing locations in Kenya (Othieno, 1988). The fatty acids were analysed as fatty acids methyl esters (Owuor et al., 1990). A typical gas chromatogram is presented in Figure 1. There is an association between the fatty acids levels in green leaf and black tea aroma compounds that are products of their degradation (Bhuyan et al., 1991) during tea processing. The distribution of fatty acids due to plucking intervals in different locations is represented in Tables $1-3$. At all plucking intervals in all locations, the levels of saturated fatty acids in the leaf varied in the order of n-hexadecanoic (palmitic) acid (C16:0) > n-octadecanoic (stearic)

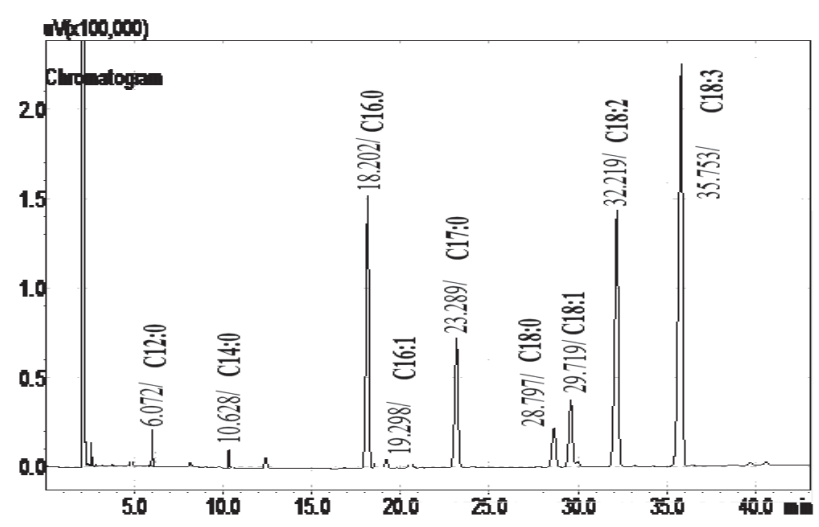

Fig. 1. Gas chromatogram of green tea leaves fatty acids methyl esters.

acid $(\mathrm{C} 18: 0)>$ n-tetradecanoic (myristic) acid (C14:0) > ndodecanoic acid (lauric) (C12:0) in all the locations (Table 1). Longer plucking intervals resulted into high levels of the fatty acids. The levels of the individual saturated fatty acids varied $(P \leq 0.05)$ with location. The extents of variations in

Table 1. The changes in saturated fatty acid (mg/g dry leaf) levels with location of production and plucking intervals.

\begin{tabular}{|c|c|c|c|c|c|c|c|}
\hline \multirow{2}{*}{ FA } & \multirow{2}{*}{ Plucking intervals } & \multicolumn{5}{|c|}{ Location } & \multirow{2}{*}{$\begin{array}{c}\text { Mean } \\
\text { plucking } \\
\text { intervals }\end{array}$} \\
\hline & & Karirana & Timbilil & Changoi & Sotik Highland & Kipkebe & \\
\hline \multirow{7}{*}{$\stackrel{\Omega}{\ddot{0}}$} & 7 days & 0.057 & 0.046 & 0.167 & 0.092 & 0.014 & 0.057 \\
\hline & 14 days & 0.087 & 0.048 & 0.184 & 0.123 & 0.048 & 0.098 \\
\hline & 21 Days & 0.136 & 0.051 & 0.263 & 0.150 & 0.188 & 0.158 \\
\hline & Mean Location & 0.093 & 0.049 & 0.205 & 0.122 & 0.083 & \\
\hline & CV $(\%)$ & & & 7.34 & & & \\
\hline & $\mathrm{LSD}, \mathrm{P} \leq 0.05$ & & & 0.009 & & & 0.017 \\
\hline & Interaction, $\mathrm{P} \leq 0.05$ & & & 0.016 & & & \\
\hline \multirow{7}{*}{$\stackrel{\Omega}{\stackrel{\leftrightarrow}{0}}$} & 7 days & 0.145 & 0.062 & 0.130 & 0.111 & 0.255 & 0.141 \\
\hline & 14 days & 0.187 & 0.064 & 0.224 & 0.128 & 0.264 & 0.174 \\
\hline & 21 Days & 0.240 & 0.075 & 0.240 & 0.147 & 0.278 & 0.196 \\
\hline & Mean Location & 0.191 & 0.067 & 0.198 & 0.129 & 0.266 & \\
\hline & CV $(\%)$ & & & 3.79 & & & \\
\hline & $\mathrm{LSD}, \mathrm{P} \leq 0.05$ & & & 0.006 & & & 0.013 \\
\hline & Interaction, $\mathrm{P} \leq 0.05$ & & & 0.012 & & & \\
\hline \multirow{7}{*}{$\stackrel{\Omega}{a}$} & 7 days & 1.414 & 1.617 & 1.269 & 1.167 & 1.537 & 1.401 \\
\hline & 14 days & 1.458 & 1.641 & 1.333 & 1.312 & 1.552 & 1.459 \\
\hline & 21 Days & 1.773 & 1.967 & 1.529 & 1.359 & 1.591 & 1.644 \\
\hline & Mean Location & 1.548 & 1.742 & 1.377 & 1.279 & 1.560 & \\
\hline & CV $(\%)$ & & & 4.33 & & & \\
\hline & $\mathrm{LSD}, \mathrm{P} \leq 0.05$ & & & 0.066 & & & 0.132 \\
\hline & Interaction, $\mathrm{P} \leq 0.05$ & & & 0.123 & & & \\
\hline \multirow{7}{*}{$\stackrel{\Omega}{\ddot{\theta}}$} & 7 days & 0.622 & 0.488 & 0.872 & 0.222 & 0.447 & 0.570 \\
\hline & 14 days & 0.856 & 0.515 & 0.887 & 0.452 & 0.474 & 0.637 \\
\hline & 21 Days & 0.979 & 0.575 & 1.016 & 0.490 & 0.526 & 0.718 \\
\hline & Mean Location & 0.819 & 0.526 & 0.925 & 0.455 & 0.483 & \\
\hline & CV $(\%)$ & & & 1.600 & & & \\
\hline & $\mathrm{LSD}, \mathrm{P} \leq 0.05$ & & & 0.011 & & & 0.021 \\
\hline & Interaction, $\mathrm{P} \leq 0.05$ & & & 0.020 & & & \\
\hline
\end{tabular}


Table 2. The changes in unsaturated fatty acid (mg/g dry leaf) levels with location of production and plucking intervals.

\begin{tabular}{|c|c|c|c|c|c|c|c|}
\hline \multirow{2}{*}{ FA } & \multirow[b]{2}{*}{ Plucking intervals } & \multicolumn{5}{|c|}{ Location } & \multirow{2}{*}{$\begin{array}{c}\text { Mean } \\
\text { plucking } \\
\text { intervals }\end{array}$} \\
\hline & & Karirana & Timbilil & Changoi & Sotik Highland & Kipkebe & \\
\hline \multirow{7}{*}{$\stackrel{\Omega}{\stackrel{\overbrace{}}{-}}$} & 7 days & 0.042 & 0.029 & 0.038 & 0.056 & 0.026 & 0.038 \\
\hline & 14 days & 0.049 & 0.030 & 0.043 & 0.059 & 0.032 & 0.043 \\
\hline & 21 Days & 0.063 & 0.032 & 0.045 & 0.065 & 0.036 & 0.048 \\
\hline & Mean Location & 0.051 & 0.030 & 0.042 & 0.060 & 0.032 & \\
\hline & CV $(\%)$ & & & 6.53 & & & \\
\hline & $\mathrm{LSD}, \mathrm{P} \leq 0.05$ & & & 0.003 & & & 0.006 \\
\hline & Interaction, $\mathrm{P} \leq 0.05$ & & & 0.006 & & & \\
\hline \multirow{7}{*}{ 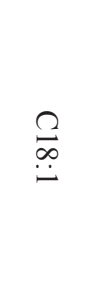 } & 7 days & 0.361 & 0.375 & 0.494 & 0.301 & 0.485 & 0.403 \\
\hline & 14 days & 0.384 & 0.386 & 0.511 & 0.322 & 0.507 & 0.422 \\
\hline & 21 Days & 0.412 & 0.411 & 0.532 & 0.347 & 0.521 & 0.445 \\
\hline & Mean Location & 0.386 & 0.391 & 0.512 & 0.323 & 0.504 & \\
\hline & CV $(\%)$ & & & 1.16 & & & \\
\hline & $\mathrm{LSD}, \mathrm{P} \leq 0.05$ & & & 0.005 & & & 0.009 \\
\hline & Interaction, $\mathrm{P} \leq 0.05$ & & & 0.008 & & & \\
\hline \multirow{7}{*}{$\underset{\infty}{\stackrel{\Omega}{\sim}}$} & 7 days & 1.617 & 1.761 & 1.226 & 1.565 & 1.428 & 1.520 \\
\hline & 14 days & 1.739 & 1.840 & 1.372 & 1.618 & 1.481 & 1.610 \\
\hline & 21 Days & 2.031 & 2.136 & 1.810 & 1.675 & 1.519 & 1.834 \\
\hline & Mean Location & 1.796 & 1.912 & 1.469 & 1.619 & 1.476 & \\
\hline & CV $(\%)$ & & & 0.74 & & & \\
\hline & $\mathrm{LSD}, \mathrm{P} \leq 0.05$ & & & 0.012 & & & 0.025 \\
\hline & Interaction $\mathrm{P} \leq 0.05$, & & & 0.023 & & & \\
\hline \multirow{7}{*}{$\underset{\infty}{\mathscr{\omega}}$} & 7 days & 2.859 & 1.990 & 1.659 & 1.943 & 1.618 & 2.014 \\
\hline & 14 days & 3.193 & 2.080 & 1.894 & 1.990 & 2.137 & 2.259 \\
\hline & 21 Days & 3.841 & 2.262 & 2.359 & 2.126 & 2.176 & 2.553 \\
\hline & Mean Location & 3.298 & 2.111 & 1.971 & 2.019 & 1.977 & \\
\hline & $\mathrm{CV}(\%)$ & & & 0.75 & & & \\
\hline & LSD, $\mathrm{P} \leq 0.05$ & & & 0.017 & & & 0.035 \\
\hline & Interaction, $\mathrm{P} \leq 0.05$ & & & 0.032 & & & \\
\hline \multirow{7}{*}{ 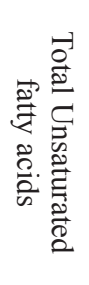 } & 7 days & 4.879 & 4.155 & 3.418 & 3.865 & 3.560 & 3.975 \\
\hline & 14 days & 5.365 & 4.336 & 3.820 & 3.989 & 4.157 & 4.334 \\
\hline & 21 Days & 6.347 & 4.840 & 4.746 & 4.213 & 4.254 & 4.880 \\
\hline & Mean Location & 5.530 & 4.444 & 3.995 & 4.022 & 3.990 & \\
\hline & CV $(\%)$ & & & 0.53 & & & \\
\hline & $\mathrm{LSD}, \mathrm{P} \leq 0.05$ & & & 0.024 & & & 0.048 \\
\hline & Interactions, $\mathrm{P} \leq 0.05$ & & & 0.044 & & & \\
\hline
\end{tabular}

Table 3. The variation of total fatty acids ( $\mathrm{mg} / \mathrm{g}$ of dry leaf) due to location and plucking intervals.

\begin{tabular}{|c|c|c|c|c|c|c|c|}
\hline \multirow{2}{*}{ FA } & \multirow{2}{*}{ Plucking intervals } & \multicolumn{5}{|c|}{ Location } & \multirow{2}{*}{$\begin{array}{c}\text { Mean } \\
\text { plucking } \\
\text { intervals }\end{array}$} \\
\hline & & Karirana & Timbilil & Changoi & Sotik Highland & Kipkebe & \\
\hline \multirow{7}{*}{ 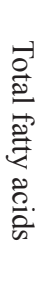 } & 7 days & 7.118 & 6.369 & 5.855 & 5.657 & 5.814 & 6.163 \\
\hline & 14 days & 7.957 & 6.604 & 6.449 & 6.005 & 6.495 & 6.702 \\
\hline & 21 Days & 9.475 & 7.508 & 7.793 & 6.358 & 6.839 & 7.594 \\
\hline & Mean Location & 8.183 & 6.827 & 6.699 & 6.007 & 6.383 & \\
\hline & CV $(\%)$ & & & 1.12 & & & \\
\hline & $\mathrm{LSD}, \mathrm{P} \leq 0.05$ & & & 0.078 & & & 0.155 \\
\hline & Interaction, $\mathrm{P} \leq 0.05$ & & & 0.144 & & & \\
\hline
\end{tabular}


the levels of the acids were not uniform. The order of concentration for n-dodecanoic acid was: Changoi $>$ Sotik Highlands $>$ Karirana $>$ Kipkebe $>$ Timbilil. For n-tetradecanoic acid the order was: Kipkebe $>$ Changoi $>$ Karirana $>$ Sotik Highlands $>$ Timbilil. The level of n-hexadecanoic acid was: Timbilil $>$ Kipkebe $>$ Karirana $>$ Changoi $>$ Sotik Highlands and the order for n-octadecanoic acid was: Changoi $>$ Karirana $>$ Timbilil $>$ Kipkebe $>$ Sotik Highlands. Although there were increases in the levels of the saturated fatty acids with plucking intervals, the rates of increases were not constant in all the locations causing significant $(\mathrm{P} \leq 0.05)$ interaction effects (Table 1). This demonstrates that similar plucking interval does not produce similar variations in levels of tea leaves saturated fatty acids in a single genotype at different locations.

The levels of the individual and total unsaturated fatty acids increased $(\mathrm{P} \leq 0.05)$ with longer plucking intervals at all locations (Tables 2 and 3), explaining in part the general black tea aroma quality declines with long plucking intervals even when plucking standard is the same (Owuor et al., 2000). The magnitudes and patterns of the changes varied with sites of production. The non-uniform variations in the levels of these acids are attributable to different climatic conditions prevailing in the different regions subjecting the plants to differences in growth parameters.

An increase in unsaturated fatty acid levels with coarse plucking standard had been observed (Owuor et al., 1990). A plucking interval encouraging harvesting more mature leaf is therefore expected to have higher fatty acids levels. However, in this study, the plucking standard was constant and selective. Only two leaves and a bud were plucked and the influence of coarse plucking was minimal. Despite maintaining same plucking standard, fatty acids levels still increased with long plucking intervals even at a single site. This demonstrates for the first time that within Kenya, there are significant $(\mathrm{P} \leq 0.05)$ variations in unsaturated fatty acid and total fatty acid levels in the shoots of one genotype subjected to the similar plucking management in different regions.

Significant differences $(\mathrm{P} \leq 0.05)$ in the level of unsaturated fatty acids with location at constant plucking interval were observed. (9Z, 12Z, 15Z)-octadecatrienoic (linolenic) acid $\left(\mathrm{C} 18: 3^{\Delta 9,12,15}\right)$ varied in the order Karirana $>$ Timbilil $>$ Sotik Highlands $>$ Kipkebe $>$ Changoi. The variation in $(9 \mathrm{Z}$, $12 Z)$-octadecadienoic (linoleic) acid $\left(18: 2^{\Delta 9,12}\right)$ was significant $(\mathrm{P} \leq 0.05)$ in all locations such that Timbilil $>$ Karirana $>$ Sotik Highlands $>$ Kipkebe $>$ Changoi. (9Z)-octadecaenoic (oleic) acid $\left(18: 1^{\Delta 9}\right)$ varied in the order Changoi $>$ Kipkebe $>$ Timbilil $>$ Karirana $>$ Sotik Highlands and (9Z)-hexadecaenoic (palmitoleic) acid $\left(\mathrm{C} 16: 1^{\Delta 9}\right)$ varied in the order Sotik Highlands $>$ Karirana $>$ Changoi $>$ Kipkebe $>$ Timbilil (Table
2). Total unsaturated fatty acid and total fatty acid levels varied significantly with location in the order Karirana $>$ Timbilil $>$ Sotik Highlands $>$ Changoi $>$ Kipkebe (Table 3). Thus, similar plucking intervals will not produce similar levels of precursors of aroma quality in parameters all areas even in one genotype, partly explaining the differences observed in black teas VFC grown in Kenya and Malawi (Owuor et al., 2008). It is important therefore that plucking management is domesticated in the regions of intended production.

Although there were significant $(\mathrm{P} \leq 0.05)$ increases in fatty acid levels with increase in plucking intervals, the increase rates were not constant in all the locations causing significant interactions effects $(\mathrm{P} \leq 0.05)$ (Table 2 and 3 ). Therefore, similar plucking intervals would lead to different levels of precursors of aroma quality parameters in different regions causing differences in tea quality. This is attributable to different growth rates in different locations ( $\mathrm{Ng}$ 'etich et al., 2001) leading to achievement of the recommended two leaves and a bud (Othieno, 1988) after different time lengths in different locations. Therefore the uniform blanket recommended plucking interval throughout Kenya (Othieno, 1988) may be subjecting some areas to low quality production. Studies on plain quality parameters on (Owuor et al., 2010a, $2010 \mathrm{~b}, 2009)$ showed same trend. This implies that each location has an optimal plucking management practice. There is need to intensify the development of region specific agronomic input levels to improve tea quality.

Acknowledgements We thank the Tea Research Foundation of Kenya for allowing the use of experimental plots and the Inter University Council of East Africa (VicRes) for the financial support.

\section{References}

Baruah, S., Hazarika, M., Mahanta, P.K., Horita, H. and Murai, T. (1986). Effects of plucking intervals on chemical constituents of CTC black teas. Agric. Biol. Chem., 50, 1039-1041.

Bhuyan, L.P., Tamuly, P. and Mahanta, P.K. (1991). Lipid content and fatty acid composition of tea shoot and manufactured tea. $J$. Agric. Food Chem., 39, 1159-1162.

Bondarovitch, H.A., Giammarino, A.S. and Renner, J.A. (1967). Some aspects of the Chemistry of tea. A contribution of knowledge of the volatile constituents. J. Agric. Food Chem., 15, 3647.

Ellis, R.T. and Grice, W.J. (1981). Fertiliser for 1981. Tea Research Foundation of Central Africa Quart. Newsl., 61, 23.

Gardner, H.W. and Salke, E. (1984). Volatiles from thermal decomposition of isomeric methyl $(12 S, 13 S)-(E)-12,13$-epoxy-9hydroperoxy-10-octadecenoates. Lipids, 19, 375-380.

Gassenmeier, K. and Schieberle, P. (1994). Formation of the intense flavor compound trans-4,5-epoxy-(E)-2-decenal in thermally 
treated fats. J. Am. Oil Chem. Soc., 71, 1315-1319.

Hatanaka, A., Kajiwara T. and Matsui, K. (1995). The biogeneration of green odour by green leaves and physiological functions- past, present and future. Z. Naturforch, 50, 467-472.

Kajiwara, T., Sekiya, J., Asano, M. and Hatanaka, A. (1982). Enantioselectivity of enzymic cleavage reaction of 13-hydroperoxylinolenic acid to $\mathrm{C}_{6}$ aldehydes and $\mathrm{C}_{12}$ oxo acid in tea chloroplasts. Agric. Biol. Chem., 46, 3087-3088.

Kumazawa, K., Wada, Y. and Masuda, H. (2006). Characterization of epoxydecenal isomers as potent odorants in black tea (Dimbula) infusion. J. Agric. Food Chem., 54, 4795-4801.

Mahanta, P.K., Baruah, S., Owuor, P.O. and Murai, T. (1988). Flavour volatiles of Assam black teas manufactured from different plucking standard and orthodox teas manufactured from different altitudes of Darjeeling. J. Sci. Food Agric., 45, 317-324.

Munavu, R.M. (1983). Croton megalocarpus hutch seed kernel oil. A potential rich source of octadeca-9, 12-decanoic acid. Kenya J. Sci. Technol., 4, (A), 77-81.

Ng'etich, W.K., Stephens, W. and Othieno, C.O. (2001). Responses of tea to environment in Kenya. 3. Yield and yield distribution. Expl Agric., 37, 361-372.

Odhiambo, H.O. (1989). Nitrogen rates and plucking frequency on tea: The effect of plucking frequency and nitrogenous rates on yield components of tea (Camellia sinensis (L.) O. Kuntze) in Kenya. Tea, 10, 90-96.

Othieno, C.O. (1988). Summary of recommendation and observations from TFRK. Tea, 9(2).

Owuor, P.O. (1996). Improving black tea quality through optimum plucking: A review. J. Plant. Crops, 24, 697-702.

Owuor, P.O., Kamau, D M. and Jondiko, E.O. (2009). Response of clonal plain black tea quality parameters and yields to geographical region of production and plucking frequencies. Food Chem., 115, 290-296.

Owuor, P.O., Kamau, D.M. and Jondiko, E.O. (2010a). Responses of clonal tea to location of production and nitrogenous fertiliser rates. J. Food Agric. Environ., 8 (2), 682-690.

Owuor, P.O., Munavu, R.M. and Muritu, J.W. (1990). Plucking standards effects and the distribution of fatty acids in the tea $(\mathrm{Ca}$ - mellia sinensis (L.O. Kuntze)) leaves. Food Chem., 37, 27-35.

Owuor, P.O., Ng'etich, W.K. and Obanda, M. (2000). Quality response of clonal black tea to nitrogen fertilizer., plucking interval and plucking standard, J. Sci. Food Agric., 80, 439 -446.

Owuor, P.O., Obanda, M., Nyirenda, H.E. and Mandala, W.L. (2008). Influence of region of production on clonal black tea chemical characteristics. Food Chem., 108, 263-271.

Owuor, P.O., Wachira, F.N. and Ng'etich, W.K. (2010b). Influence of region of production on relative clonal plain tea quality parameters in Kenya, Food Chem., 119, 1168-1174.

Ramaswamy, R. and Ramaswamy P. (2000). Lipid occurrence, distribution and degeneration to flavour volatiles during tea processing. Food Chem., 68, 7-13.

Robinson, J.M. and Owuor, P.O. (1992). Tea aroma. In "Tea Cultivation to Consumption" ed by K.C. Willson and M.N. Clifford, Chapman and Hall, London, 1st Ed, Chapter 18, pp 603-647.

Sanderson, G.W. and Graham, H.N. (1973). On the formation of black tea aroma. J. Agric. Food Chem., 21, 576-585.

Sekiya, J., Kajiwara, T. and Hatanaka, A. (1984). Seasonal changes in the activities of enzymes responsible for the formation of $\mathrm{C}_{6}$ aldehydes and alcohols in tea leaves and the influence of environmental temperatures on the enzyme activities. Plant Cell Physiol., 25, 269-280.

Sharma, V.S. (1987). Harvest in tea. Planters Chronicle, 82(8), 261 266.

Skobeleva, N.I., Petrova, T.A. and Bukuchava, M.A (1987). On the pathways of tea aroma formation. Proc. Intern. Tea Symp., Rize, Turkey, June, 1982 pp. 141-144.

Takeo, T. and Mahanta, P.K. (1983). Comparison of black tea aromas of orthodox and CTC tea and of black teas made from different varieties. J. Sci. Food. Agric., 34, 307-310.

Wang, Y.G., Cheng, Q.K. and Ruan, Y.C. (1988). Discussion on the chemical standards on quality of Chinese roasted green tea. $J$. Tea Sci., 8(2), 13-20.

Yamanishi, T., Wickremashinghe, R. and Perera, K.P.W.C. (1978). Studies on flavour and quality of tea. 3. Gas chromatographic analysis of aroma complex. Tea Quart., 39, 81-86. 